\begin{tabular}{|lc|}
\hline JUIRINAU & Jurnal Pendidikan Vokasi \\
PENDIDIKAN & Volume 8, No 2, June 2018 (173-183) \\
VOKASI & Online: http://journal.uny.ac.id/index.php/jpv \\
\hline \hline
\end{tabular}

\title{
EDUCATION MEDIA DEVELOPMENT FOR CLUTCH (EMC) IN VOCATIONAL EDUCATION: THE CONCEPT OF CLUTCH WORK
}

\author{
Muhammad Nurtanto \\ Department of Mechanical Engineering Education, Universitas Sultan Ageng Tirtayasa \\ mnurtanto23@untirta.ac.id
}

\begin{abstract}
This development research aims to describe the working concept of EMC with VPE valuation method. The EMC quality is based on following aspects: (1) valid according to experts; (2) practical according to practitioners; and (e) effective based on students ability test. The developed cycles and procedures refer to the ADDIE model (analysis, design, development, implementation, and evaluation). Data was collected using rating scale sheet (1-5) and percentage of learning using EMC outcomes. The research results show that the valid and practical aspects of the category are valid and practical enough with an average score of $3.68(73.6 \%)$ and $3.75(75.0 \%)$ respectively. While the results of the effective test obtained an average score of 3.74 (74.8\%) and the competence test results is $80.51 \%$. The advantages of EMC are attractive design, practical size, and ease of use (user-friendly). Students recommend that they enjoy learning with EMC and it supports learning about chassis.
\end{abstract}

Keywords: $E M C, V P E$, and clutch 


\section{INTRODUCTION}

Learning is an interaction process of knowledge transfer (Duangchant, Kiattikomol, \& Kaewkuekool, 2016) between teacher and students to achieve learning outcome. The success of the interaction process is indicated by changes in the students' mindset and also behavior into a better state than before.

The knowledge transfer process takes place in a quite complicated manner. This means that the process of information and messages exchange between teacher and students is influenced by many factors. However, good communication requires appropriate tools or media that supports quick and accurate information exchange. In relation to this requirements, teachers must be able to choose the appropriate tools.

Tools in the form of educational media that is suitable with the characteristics of competence being taught and of the students, will give good learning impression, message and experience. In addition, the tools in the learning process is used to facilitate comprehension about the subjects delivered by teacher (Sugiarto, 2010, p.7) so it can be accepted easily by students in the form of fresh and indepth learning experiences. The tool can be either visual or non-verbal media. The media used, when it involves all the senses, will achieve much higher success rate. In addition, the media can be functioned as a translator or to expand the boundaries of a process that can't be seen directly by the senses. So this kind of media should be able to simulate the process itself.

Mechanical engineering education program has class for competency theory of chassis, and chassis practice which has 4 credits. The expected graduate competence is to master the factual, conceptual, procedural, and meta-cognitive dimensions of knowledge and implement them on real conditions. Understanding the factual and conceptual dimensions is relatively easier, but on the other hand, understanding the procedural and even Meta-cognitive dimensions is trickier. Some principles can't be observed by the senses directly, for example the work of clutch involving the motion of several components. The process of change of each components cannot be observed directly but the result of the working principle can felt. Those dimension levels can lead to students' misconceptions, because the working components are concealed inside the clutch housing.

Below is the observation result showing the grades of understanding for 34 PTM 2014/2015 students on chassis competence: clutch based on the gradation of factual, conceptual, procedural, and Meta-cognitive dimension, before using Education Media Clutch (EMC):

Table 1. Learning Results before EMC

\begin{tabular}{lcc}
\hline \multicolumn{1}{c}{ Knowledge Dimension Gradation and Competence Indicator } & IC & C \\
\hline Factual Knowledge Dimension & $24 \%$ & $76 \%$ \\
a. Clutch location/position & $56 \%$ & $44 \%$ \\
b. Clutch components & $38 \%$ & $62 \%$ \\
c. Clutch types & $39 \%$ & $61 \%$ \\
Average & & \\
Conceptual Knowledge Dimension & $59 \%$ & $41 \%$ \\
a. Clutch dismantling steps & $71 \%$ & $29 \%$ \\
b. Clutch measurement steps & $65 \%$ & $35 \%$ \\
c. Clutch assembling steps & $65 \%$ & $35 \%$ \\
Average & & \\
Procedural Knowledge Dimension & $76 \%$ & $24 \%$ \\
a. Doing clutch dismantling & $76 \%$ & $24 \%$ \\
b. Explaining clutch work process in real condition & $88 \%$ & $26 \%$ \\
c. Measuring and repairing clutch & $88 \%$ & $26 \%$ \\
d. Assembling clutch without damaging & $79 \%$ & $21 \%$ \\
Average & & \\
Meta-cognitive Knowledge Dimension & $88 \%$ & $12 \%$ \\
a. Dismantling, measuring, and assembling with proper procedure & $100 \%$ & $0 \%$ \\
b. Repairing clutch on other vehicle & $96 \%$ & $4 \%$ \\
Average & & \\
\hline Note: C. Complate and IC: Incomplete (Source: Document of Chassis Competence Test Result, 2017 )
\end{tabular}

Note: C: Complate and IC: Incomplete (Source: Document of Chassis Competence Test Result, 2017) 


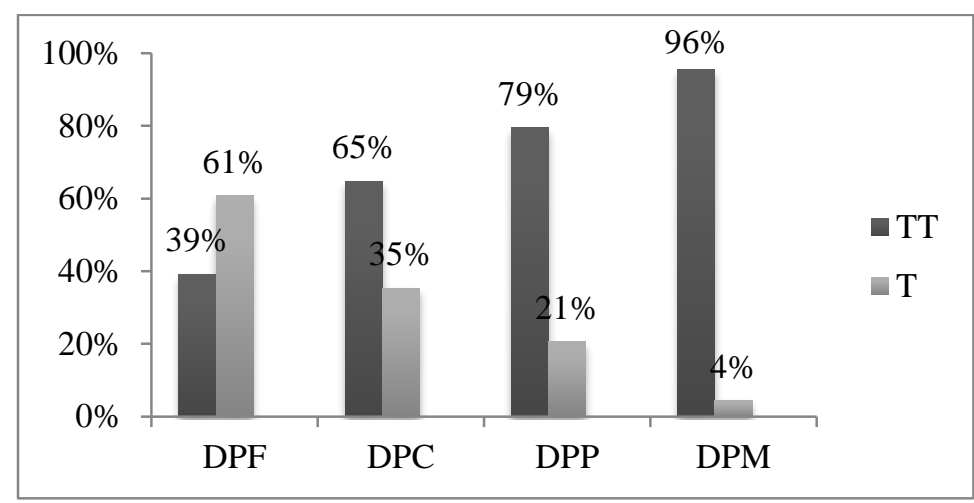

Figure 1. Diagram of Learning Result for Gradation Clutch Knowledge Dimension

Based on the learning outcomes shown in table 1 . Students in the complete category for factual dimension is $61 \%$, conceptual dimension is $35 \%$, but only $21 \%$ for procedural dimension and $4 \%$ for metacognitive dimension. For the knowledge dimension of factual and conceptual, students can learn their clutch competence from the observation using their senses, while the procedural knowledge dimension about the process cannot be observed directly with the senses. This condition suppresses the students' learning motivation. Moreover, the metacognitive dimension can notbe implemented properly, because it requires special skills beyond the previous three dimensions.

The abstract and limited natures of verbal media (images, video, text, etc.) make clutch competence has not been maximum. Therefore, it needs a media that can deliver the information easily, effectively and feasible. This leads to the development of clutch Media Education by showing the working components of clutch that can be observed directly. The procedure developed in EMC is cutting the media without damaging the mechanism of motion. This process requires good planning and implementation.

As a solution for those problems, it is required to have tools or media that can overcome the limitation or space boundary to make students understand about the concept of how centrifugal clutch work. The required media is the media which has the same concept with the original object. So it takes research of EMC development with VPE method.

EMC comes in many varieties, shapes and characteristics. EMC clarifies the abstract message (Sangsawang, 2015) to become concrete message, thus facilitating the understanding of concepts. Therefore EMC helps students to understand the application of a learning material in a different way in the learning process (Hidayati \& Wuryandari, 2012; Sugiarto, 2010, p. 7).

The first development of education media in the field of education was in learning mathematics. The reason was to facilitate mastery of the logic concept for students, because without the tools the thinking process would take longer. In the same way, EMC is needed in automotive learning for complicated systems or mechanisms. Through EMC those complicated system or mechanism is made simpler so the mastery of concept can be more focused. This is possible because the system is separated from other systems. In addition, EMC does not reduce the learning objectives to be achieved and clarifies certain parts of the automotive field that cannot be observed directly. So the principle of EMC is to simplify the parts of the component or system by removing it from the original position without changing the working mechanism, and it is used to facilitate understanding in the learning concept.

EMC to be developed is the diaphragm type clutch or also called with friction clutch. Diaphragm clutch is the most used practice media in automotive vocational education. This means that this type of clutch is already taught before. In addition to being easy to obtain, this type is not so complicated compared to hydraulics, magnets, and torque converter types.

The purpose of EMC is to improve the quality of learning, meaning the quality of 
learning can be increased. Also, learning can be more effective, focused, attractive and also can improve the students' metacognitive. The main benefit of this media is eliminating the abstract or imaginative nature. If students are taught only verbally then their abilities are verbal also, while the ability to understand the concept is very poor. Thus, these problems will be solved by using EMC and students can learn through direct experience (experiential learning) that will result in a good metacognitive concept (Murti, 2011).

The field of engineering needs innovation in its education to build a conceptual understanding, one of which is EMC. Researches that have been conducted in other fields include (Hermanto \& Margo Sulistyo, 2012). The result of this research concluded that the use of power window panels can improve student learning outcomes than without power window panels. (Wicaksono, Hadromi, \& Masugino (2013) with research of Application of Motorcycle Lighting System Display Panel increased by 26.74 (58.5\%). Rahmawan, Widjanarko, \& Wahyudi (2012) props of charging system based on circuit work can increase student learning outcomes by an average of 8.64 or $18.2 \%$. (Nopilar \& Saputro (2011) with research on The Implementation of Ignition System Display Panel observed an improvement in the understanding by $27.33(57.33 \%)$. Based on the results of the above researches, it can be concluded that the media developed are the same that is media props. It was developed for other competencies and the results are an increased outcome. The visual props developed for this research is EMC, to provide new benefits and innovations and improve positive perceptions. According to Shabiralyani, Hasan, Hamad, \& Iqbal (2015), the majority of the teachers and students have positive perceptions of the use of visual aids. This research focus on the development process and assessment of props to be used as EMC.

The above reasons support the argument for auxiliary role without changing the principles, working mechanisms or component forms, but facilitate in understanding the material (Sastradiradja, 1971, p. 4). The impact of teaching aids is improving memory comprehensively and profoundly ( $\mathrm{Li}$, Tan, Teo, \& Wei, 2012) and improving critical thinking and problem-solving skills as well (Kadlowec, Lockette, \& Bukumaran, 2002).

\section{Education Media for Clutch}

Clutch is a member of chassis group located between flywheel and transmission. The function is to adjust the power that is transmitted from the engine to the transmission and then the transmission changes the machine speed as desired. The way it works is to disconnect and connect transmission rotation in quick, smooth and gentle manner (Chen et al., 2017) taking into account the coefficient of friction (slip) (Arndt, Tarasow, Bohn, Wachsmuth, \& Serway, 2016) to provide comfort for the riders (p.80). In addition, the purpose of clutch is also to reduce the time of gearshift and smooth clutching process without any torque reduction (van Berkel, Hofman, Serrarens, \& Steinbuch, 2014). Its location is inside the clutch housing, which makes the mechanism of the working components cannot be observed directly. Diaphragm clutch mechanism consists of several moving components including: (a) fly wheel, (b) clutch disc, (c) pressure plate, (d) clutch cover, (e) spring diaphragm, (f) release bearings, (g) release fork. The mechanism of each component is interrelated during its operational moments. However, the process is not observable directly which results in the difficulty to provide direct understanding and comprehension to students.

\section{Development of Education Media}

The process of knowledge transfer needs supporting media to facilitate the acceptance of conceptual understanding and information storage in a relatively long period of time. In the world of education, especially vocational education, supporting media is needed. The nature of the material that is abstract, limited to theoretical and imaginative explanation without involving the senses, makes the role of supporting media as learning solutions. This learning support is what is meant by teaching support tools. 


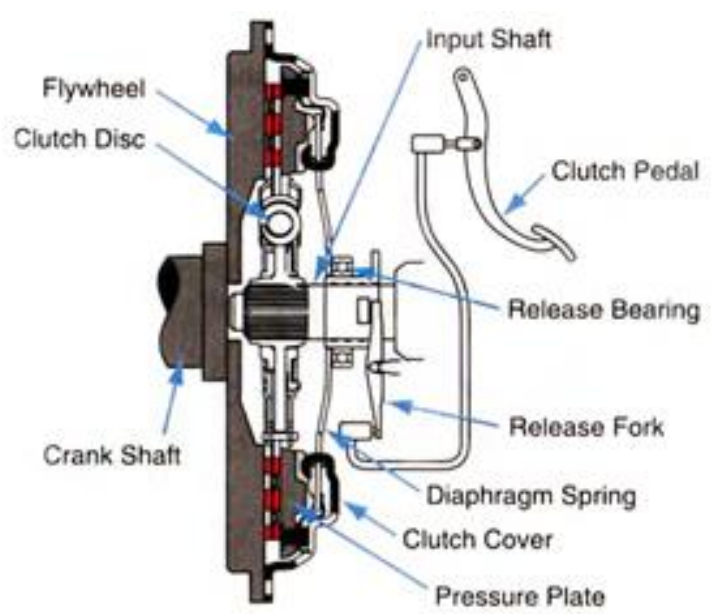

(a)

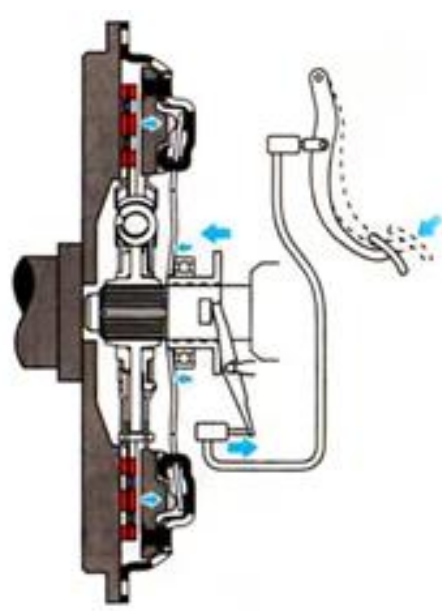

(b)

Figure 2. The concept of clutch work (a) the coupling position is connected, and (b) the clutch position is detached

The teaching aids is the educational media acting as learning stimulus, which can be absorbed by eyes and ears with the purpose of supporting the learning process, (Sudjana, 2009 , p. 59) to improve the students' competence, (Riyadi, n.d.).The props also referred to as a supporting tools which means that the learning process does not have to use props as the messenger. It is not enough for the learning process to rely on props alone, there must be someone who communicate the material to avoid trial and error and wider understanding beyond design. The learning aids serves as a means of communication and interaction, (Arsyad, 2011) to deliver informations, (Widiyatmoko \& Pamelasari, 2012), in the form of description about the work mechanism of an object, (Husnul, Nurhayati, \& Jumadi, 2015), so as to stimulate the students' mind, feelings, interests and attention.

The function of props has been explained by Sastradiradja (1971, pp. 1-3), those are: (1) helping students to learn more, (2) helping students to remember more, (3) bringing effective stimuli for learning, (4) making learning to be more concrete in nature, (5) bringing the outside world into the classroom, and (6) giving sharp image approaches from the same subject.

The benefits of learning using props (Aji, 2016) are as follows: (a) allows for direct interaction between students and the environment; (b) can produce uniform observations by students; (c) instilling the basic concepts that are true, concrete, and realistic; (d) stimulating new curiosity, joy, and interest; (e) generating motivation and stimulating student to learn; (f) providing an integral experience from a concrete entity to abstract; (g) help remember longer; (h) bringing the world into the classroom

Good props must fulfil several criteria (Sastradiradja, 1971, pp. 4-7), they should be designed based on consideration of teacher conditions, should be simple, clear and in correct form so they will not be confusing. The requirements that should be met from a learning aids are rational, scientific, economical, practical and functional. They are stressed by Sundayana $(2015$, p. 8$)$ that the requirements and criteria for education props are durable, attractive in shape and color, simple and manageable, of appropriate size, can present the concept, in accordance with the concept, clarify the concepts and basic concepts of abstract thinking.

The props can be in the form of real objects, drawings or diagrams. The advantages of real object props are movable or able to be manipulated, while their weaknesses are the fact that they cannot be presented in a book or in writing. Educational props is a visual tool developed from its original form into a simpler view with the objective of facilitating comprehension in learning. The development should be done when learning on the actual conditions is very difficult to stimulate cognitive understanding. The props are made 
to anticipate limitations of senses in learning. The position of visual aids is as a factual, conceptual, procedural and metacognitive translator that is modified as requirement.

Implementation of educational tools for diaphragm type clutch is based on several strong reasons: (a) clutch working mechanism cannot be observed directly, (b) the location of clutch is complicated as a medium of understanding the concept, (c) requires a relatively long time to understand the components, (d) integrated with other system (transmission and fly wheel), (e) explanation using images, without seeing the real thing, is not enough.

\section{EMC Assessment Using VPE Method}

EMC development must follow a standard or fulfil the eligibility to be used in learning. The standard is intended to ensure that the values and purposes of the learning objectives are met. The process of obtaining this standards is called (Fatkhurrokhman, Permata, Ekawati, \& Rizal, 2017) validation, practical and effective aspects of the EMC media and is carried out by someone skilled in the science or substance or practitioner and user (Fawaid, Nurhaji, Nurtanto, \& Ramdani, 2017). Expert validation is used to test the validity of props (Amin Fatah, 2015). The teaching aids as educational media simulation is considered valid after testing by experts, practitioners and users (Nurtanto, 2016).

Expert validation test involves several experts from universities in automotive field, training center that is BBLK Serang for automotive and LSP Atom for automotive as competence expert in this field. The practitioner's test involves the practitioner experts who are teachers and lecturers for the chassis subjects or competence. And the effective test is done through small or limited group test, involving students as users. They are from PTM-Untirta.

The EMC assessment was based on media criteria and requirements of props that are grouped into four aspects with each expert of different indicators. Thevalidation aspects in question are (a) display, (b) size, and (c) use of props. Practical aspects are (a) conformity of mechanism, (b) coupling performance, and (c) conformity of coupling manual. The effective aspects are based on (a) attractiveness, (b) the benefits of EMC, and (c) convenience. Next, EMC is tested against the students' competence with indicators (a) the factual dimension, (b) the conceptual dimension, (c) the procedural dimension; and (d) metacognitive dimensions. Each aspect must either exceed or above "enough". This means that the media has met the requirements criteria to be used as a media simulation in education, especially on clutch competence in vocational education.

\section{RESEARCH METHOD}

The type is Research \& Development with the aim to develop EMC on clutch work. The orientation of this development research is to produce a valid and feasible EMC product for use in the learning process.

The development steps adapt the ADDIE model which has five stages, namely: Analysis, Design, Development, Implementation and Evaluation. This model is selected because (Abd Rahman, Ismail, \& Nasir, 2014; Cheung, 2016; Linh \& Suppasetseree, 2016) ADDIE is an appropriate model for development research due to its sequential and interactive development process, in which the evaluation of each stage can bring learning development to the next stage.

EMC's development cycle and procedures are as follows Figure 3.

Subjects in this study are based on the VPE method. Valid EMC is then tested to 5 media experts. Practical EMC is tested to the user of 7 teachers and lecturers. And then Effective is tested based on the 30 students' competence.

The quantitative data obtained is then analyzed (Sukardi et al., 2007), by presenting the percentage (Mardapi, 2008, p. 94) and descriptively converted (BEHERA, n.d.), according to Likert scale (1-5) and percentage of competence test results. 


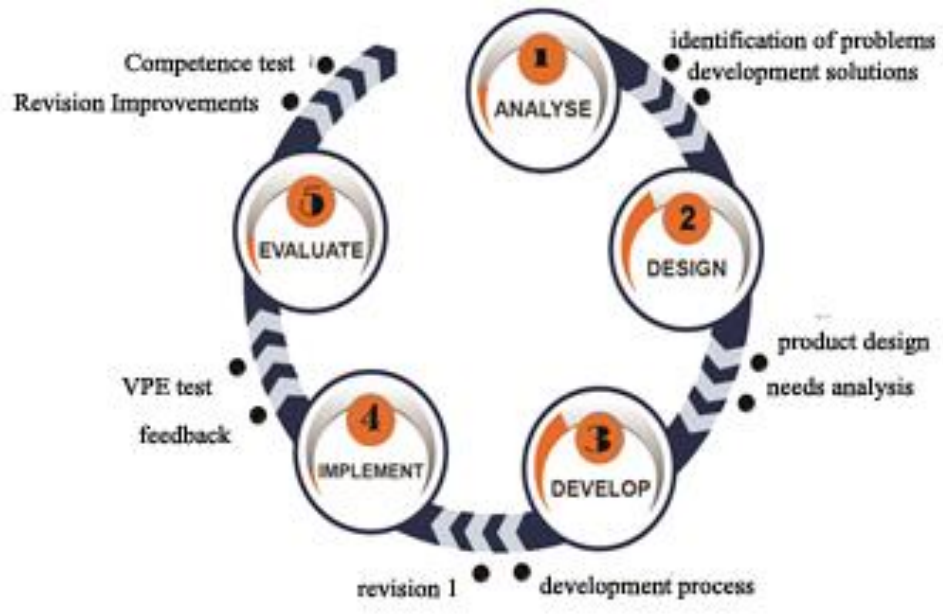

Figure 3. ADDIE Cycle on EMC

\section{RESULT AND DISCUSSION}

After the development phase using ADDIE and the product has met the requirement analysis, then it is tested to expert, practitioner and user of EMC. The results obtained as follows Table 2.

Based on Azwar (2013, p. 93) criteria, the rating category are as follows: if $4.9<\mathrm{X}$, then it is categorized as very valid EMC; if the score is $4<\mathrm{x} \leq 4.9$, then it is categorized as valid EMC; if the score is $3.2<\mathrm{X} \leq 4$, then it is categorized as EMC quite valid; if the score is $2.3<\mathrm{x} \leq 3.2$, then categorized as invalid EMC; and if the score is $\mathrm{X} \leq 2.3$, then it is categorized as very invalid EMC. Based on Table 2 the average is 3.68. Therefore
EMC is quite valid or sufficient to meet the requirement.

Table 2. Result of EMC-Valid Test

\begin{tabular}{llc}
\hline $\begin{array}{c}\text { Assessment } \\
\text { Valid Aspect }\end{array}$ & \multicolumn{1}{c}{ Indicator } & $\begin{array}{c}\text { Average } \\
\text { Score } \\
(1-5)\end{array}$ \\
\hline 1. Display & 1.1. Attractive Design & 3,8 \\
& 1.2. Suitable Color & 3,6 \\
& 1.3. Correct & 3,4 \\
2. Size & $\quad$ Component Layout & \\
3. Use of Props & 2.1. Practical Size & 3,8 \\
& 3.1. Easy to Use & 3,8 \\
& 3.2. Save to Use & 3,4 \\
& 3.3. Average Score & 3,68 \\
\hline
\end{tabular}

Table 3. Result of EMC-Practical Test

\begin{tabular}{cllc}
\hline \multicolumn{2}{c}{ Assessment Practical Aspect } & \multicolumn{1}{c}{ Indicator } & Average Score (1-5) \\
\hline 1. & Mechanism Conformity & 1.1. Props Mechanism conforms & 3,6 \\
2. EMC Performance & 2.1. Tools and components work well & 3,4 \\
3. Manual Conformity & 3.1. Simulation for worn out clutch & 4,2 \\
& & 3.2. Simulation for clutch gap adjustment & 3,8 \\
& 3.3. Simulation for movement mechanism & 3,2 \\
& Average Score & 3,75 \\
\hline
\end{tabular}

Table 4. Result of EMC-Effective Test

\begin{tabular}{llll}
\hline \multicolumn{2}{c}{$\begin{array}{c}\text { Assessment Effective } \\
\text { Aspect }\end{array}$} & \multicolumn{1}{c}{ Indicator } & Average Score (1-5) \\
\hline 1. & Attractiveness & 1.1. Attractive Design & 3,8 \\
& & 1.2. Fun to Learn with & 4,2 \\
& & 1.3. Interesting use of Color & 3,4 \\
2. EMC Benefit & 2.1. Motivates Learning & 3,6 \\
& & 2.2. Helps with the comprehension & 3,8 \\
& & 2.3. Support the learning process & 4,2 \\
3. Convenience & 3.1. Props usage & 3,2 \\
& & Average Score & 3,74 \\
\hline
\end{tabular}




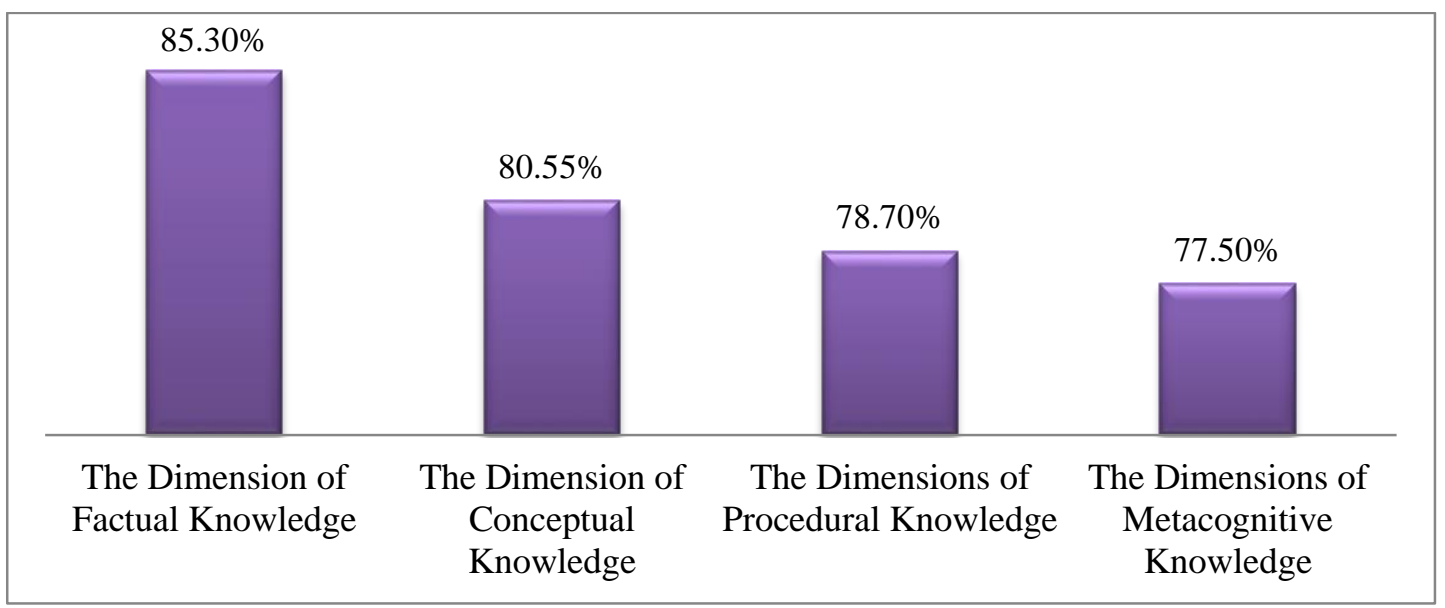

Figure 4. EMC-Capacity Test Results Diagram

Based on Figure 4. (a) There are 16\% EMC is invalid, (b) $21 \%$ EMC is impractical, and (c) $6 \% \mathrm{EMC}$ is ineffective. Thus some do not meet the criteria. The causes include: the developed product does not fully have an attractive design, even EMC cutting size is still very minimal or limited. In addition, the EMC's working mechanism demonstration is not yet in line with engine performance. From the EMC-practical testing, the average of 3.75 $(75 \%)$ is in the category of quite practical. While the EMC-effective test obtained average $3.74(74.8 \%)$ that is quite effective category. The results used in the EMC capability test obtained an average of 80.51 in the "good" category. The overall distribution and percentage can be observed in Figure 5.

The application of EMC to the concept of clutch work has fulfilled the requirement that it is tested to 5 expert practitioners. Assessment criteria are well measured includ- ing display, size and use of EMC. The results obtained in the category are quite valid, so that EMC can be used as a learning aids or developed further based on recommendations. The advantages of EMC based on expert testing are as stated: attractive design, practical size, and easy to use.

Based on the requirements when tested by the user or practitioner, the result obtained is higher that is $3.75(75.0 \%)$ on scale $1-5$ and increased 0.70. The advantage of EMC is at the simulation of worn out clutch that has 4.2 score (scale 1-5). It supports the metacognitive knowledge dimension, meaning that it can be applied to EMC.

When tested to the user through a closed statement, average score obtained is $3.74(74.8 \%)$ on scale $1-5$. Students recommend that they feel that they are learning something using EMC and that it supports their chassis learning.

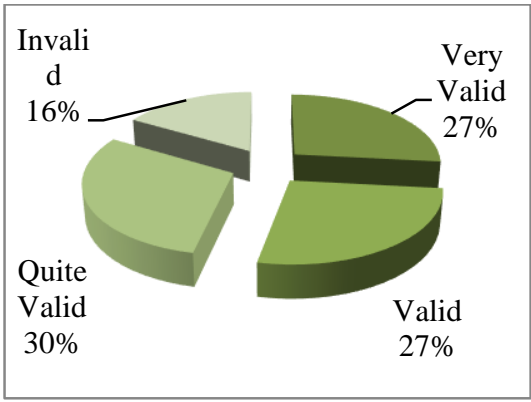

(a)

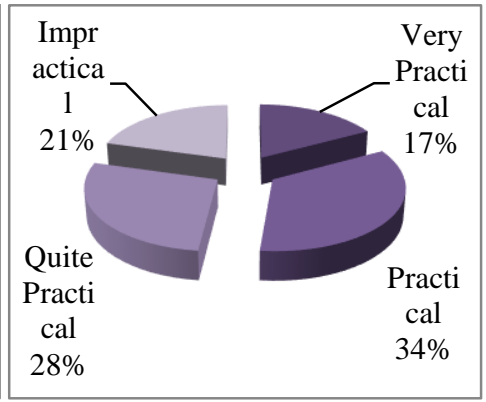

(b)

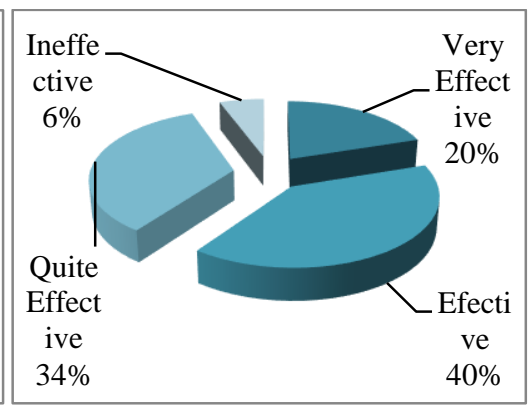

(c)

Figure 5. (a) Distribution of EMC-Valid, (b) Distribution of EMC-Practical, and (c) Distribution of EMC Effective 
After requirements have been fulfilled, then the Tests that refer to the level of knowledge dimensions that have been described previously is conducted. The average score obtained is $80.51 \%$. This indicates that the competence dimension can function well. Props, as a media EMC simulation, is feasible to be used and able to improve student's comprehension. Research conducted Wibowo et al.(2016) concluded that Virtual Media on physics learning provides comprehension to students and improves learning outcomes effectively (Sukir, Soenarto, \& Soeharto, 2017). It is also supported commercially by (Gudipadu, Sharma, \& Singh, 2015) by studying the effects of media under different conditions, this is in line with the concept of coupling with the concept of abstract work based on its position.

\section{CONCLUSIONS}

Based on the results of EMC development for competence in chassis theory and practice using ADDIE approach, the simulation media of EMC produced can fulfill the valid, practical and effective requirements as well as support the knowledge dimension: factual, conceptual, procedural, and metacognitive. The developed EMC has the following qualities: (1) the assessment performed based on valid test indicates that EMC is "valid enough" with score of 3.68 (73.6\%); (2) the assessment based on practical tests indicates that EMC is "practical enough" with score of 3.75 (75.0\%); and (3) assessments made under the effective test, the score is $3.74(74.8 \%)$. After tested for comprehension in the clutch competence using EMC, the average dimension ability is $80.51 \%$.

The advantages of developing EMC based on test results are attractive design, practical size, and easy to use to support metacognitive knowledge dimension. Students recommend that they feel like learning to use EMC and it can support in chassis learning, especially in improving dimensional comprehension.

\section{REFERENCES}

Abd Rahman, M. J., Ismail, M. A. H., \& Nasir, M. (2014). Development and Evaluation of the Effectiveness of
Computer-Assisted Physics Instruction. International Education Studies, 7(13). https://doi.org/10.5539/ies.v7n13p14

Aji, V. G. (2016). Pengembangan alat peraga penjumlahan bersusun matematika untuk meningkatkan pemahaman konsep penjumlahan siswa sekolah dasar (Skripsi). Universitas PGRI Yogyakarta.

Amin Fatah, 5201410069. (2015, February). Pengembangan Alat Peraga Sistem Starter Pada Kompetensi Dasar Diagnosis Gangguan Sistem Starter Sepeda Motor (other). UNIVERSITAS NEGERI SEMARANG.

Arndt, T., Tarasow, A., Bohn, C., Wachsmuth, G., \& Serway, R. (2016). Estimation of the clutch characteristic map for wet clutch transmissions considering actuator signal and clutch slip. IFAC-PapersOnLine, 49, 742-748. https://doi.org/10.1016/j.ifacol.2016.08.1 08

Arsyad, A. (2011). Media pembelajaran. Jakarta: PT Raja Grafindo Persada.

Azwar, S. (2013). Metode penelitian. Yogyakarta: Pustaka Pelajar.

BEHERA, S. K. (n.d.). M-learning: a new learning paradigm. - Penelusuran Google.

Chen, L., Liu, F., Yao, J., Ding, Z., Lee, C., Kao, C., ... Yin, C. (2017). Design and validation of clutch-to-clutch shift actuator using dual-wedge mechanism. Mechatronics, 42, 81-95. https://doi.org/10.1016/j.mechatronics.2 017.01 .004

Cheung, L. (2016). Using the ADDIE Model of Instructional Design to Teach Chest Radiograph Interpretation. Journal of Biomedical Education, 2016, 1-6. https://doi.org/10.1155/2016/9502572

Duangchant, S., Kiattikomol, P., \& Kaewkuekool, S. (2016). Knowledge transfer in B-O-R-N Model to enhance computer learners' learning outcomes in knowledge and cognitive skills. The Learning Organization, 23(2/3), 170183. https://doi.org/10.1108/TLO-072015-0041 
Fatkhurrokhman, M., Permata, E., Ekawati, R., \& Rizal, S. U. (2017).

Pengembangan perangkat pembelajaran teknik digital berbasis project based learning di jurusan pendidikan teknik elektro. Jurnal Pendidikan Vokasi, 7(1), 101-109. https://doi.org/10.21831/jpv.v7i1.12547

Fawaid, M., Nurhaji, S., Nurtanto, M., \& Ramdani, S. D. (2017). Perancangan Media Pembelajaran Sistem Kelistrikan Luar Mobil. VANOS Journal of Mechanical Engineering Education, 2(1). https://doi.org/10.30870/vanos.v2i1.196 5

Gudipadu, V., Sharma, A. K., \& Singh, N. (2015). Simulation of media behaviour in vibration assisted abrasive flow machining. Simulation Modelling Practice and Theory, 51, 1-13. https://doi.org/10.1016/j.simpat.2014.10. 009

Hermanto, B., \& Margo Sulistyo, S. (2012). Penggunaan panel peraga power window untuk meningkatkan hasil belajar kompetensi kelistrikan tambahan. Jurnal Pendidikan Teknik Mesin Unnes, 12(1).

Hidayati, N., \& Wuryandari, A. I. (2012). Media design for learning Indonesian in junior high school level. Procedia Social and Behavioral Sciences, 67, 490-499. https://doi.org/10.1016/j.sbspro.2012.11. 354

Husnul, I. S., Nurhayati, B., \& Jumadi, O. (2015). Pengaruh Penggunaan Media Alat Peraga Terhadap Hasil Belajar Siswa pada Materi Sistem Peredaran Darah Kelas VIII SMP Negeri 2 Bulukumba. Sainsmat, 4(1). https://doi.org/10.2685/sainsmat4112802 015

Kadlowec, von, Lockette, C., \& Bukumaran, C. (2002). Hands-on Learning Tools for Engineering Mechanics, 10.

Li, M., Tan, C.-H., Teo, H.-H., \& Wei, K.-K. (2012). Effects of product learning aids on the breadth and depth of recall. Decision Support Systems, 53(4), 793 801. https://doi.org/10.1016/j.dss.2012.05.01 6

Linh, N. D., \& Suppasetseree, S. (2016). The Development of an Instructional Design Model on Facebook Based Collaborative Learning to Enhance EFL Students' Writing Skills. IAFOR Journal of Language Learning, 2(1). https://doi.org/10.22492/ijll.2.1.04

Mardapi, D. (2008). Teknik penyusunan instrumen tes dan nontes. Yogyakarta: Mitra Cendikia Press.

Murti, H. A. S. (2011). Metakognisi dan Theory of Mind (ToM). Jurnal Psikologi: PITUTUR, 1(2), 53-64.

Nopilar, A., \& Saputro, D. D. (2011). Penerapan panel peraga sistem pengapian dalam pembelajaran model cooperatif learning untuk meningkatkan prestasi belajar kelistrikan otomotif. Jurnal Pendidikan Teknik Mesin, 11(1).

Nurtanto, M. (2016). Pengembangan Multimedia Pembelajaran Servis Sepeda Motor Ditinjau Dari Kriteria Pendidikan, Tampilan Program dan Kualitas Teknis. VANOS Journal of Mechanical Engineering Education, 1(1). https://doi.org/10.30870/vanos.v1i1.831

Rahmawan, A., Widjanarko, D., \& Wahyudi, W. (2012). Peningkatan kompetensi pengukuran sistem pengisian dengan penerapan alat peraga sistem pengisian berbasis kerja rangkaian. Jurnal Pendidikan Teknik Mesin, 12(2)

Riyadi, T. (n.d.). Meningkatkan Kompetensi Siswa Dalam Perawatan Dan Perbaikan Sistem Stater Melalui Contextual Teaching And Learning (CTL) Dengan Panel Peraga Multifungsi Pada Siswa | GARDAN.

Sangsawang, T. (2015). Instructional Design Framework for Educational Media.

Procedia - Social and Behavioral Sciences, 176, 65-80. https://doi.org/10.1016/j.sbspro.2015.01. 445

Sastradiradja, T. (1971). Media dan alat peraga pembelajaran. Jakarta: Indeks.

Shabiralyani, G., Hasan, K. S., Hamad, N., \& 
Iqbal, N. (2015). Impact of visual aids in enhancing the learning process case research: District Dera Ghazi Khan. Journal of Education and Practice, 6(19), 226-233.

Sudjana. (2009). Berbagai media gambar sebagai alat peraga. Jakarta: Pustaka.

Sugiarto. (2010). Workshop pendidikan matematika II. Semarang: Universitas Negeri Semarang.

Sukardi, Pardjono, Syamsi, K., Paidi, Prayitno, E., \& Sukamti. (2007). Panduan penelitian tindakan kelas. Yogyakarta: Lembaga Penelitian Universitas Negeri Yogyakarta.

Sukir, S., Soenarto, S., \& Soeharto, S. (2017). Developing conveyor trainer kit for programmable logic controllers in practical learning. Jurnal Pendidikan Vokasi, 7(3), 329-339. https://doi.org/10.21831/jpv.v7i3.15352

Sundayana, H. R. (2015). Media dan akat peraga dalam pembelajaran matemarika. Bandung: Alfabeta.

van Berkel, K., Hofman, T., Serrarens, A., \& Steinbuch, M. (2014). Fast and smooth clutch engagement control for dual- clutch transmissions. Control Engineering Practice, 22, 57-68. https://doi.org/10.1016/j.conengprac.201 3.09.010

Wibowo, F. C., Suhandi, A., Rusdiana, D., Darman, D. R., Ruhiat, Y., Denny, Y. R., \& Fatah, A. (2016). Microscopic virtual media (MVM) in physics learning: case study on students understanding of heat transfer. Journal of Physics: Conference Series, 739(1), 012044. https://doi.org/10.1088/17426596/739/1/012044

Wicaksono, T. A., Hadromi, \& Masugino. (2013). Penerapan Panel Peraga Sistem Penerangan Sepeda Motor Sebagai Upaya Untuk Meningkatkan Hasil Belajar Siswa SMK Negeri 1 Tengaran. Automotive Science and Education Journal, 2(1).

Widiyatmoko, A., \& Pamelasari, S. D. (2012). Pembelajaran berbasis proyek untuk mengembangkan alat peraga IPA dengan memanfaatkan bahan bekas pakai. Jurnal Pendidikan IPA Indonesia, 1(1). 